Ann. Biol. anim. Bioch. Biophys., I973, 13 (2), I65-170.

\title{
THE PATTERN OF STRUCTURAL CHANGES INDUCED IN BULL SPERMATOZOA BY ORAL OR INJECTED ETHYLENE DIBROMIDE (EDB) ()
}

\author{
D. AMIR and E. BEN-DAVID * \\ Division of Animal Reproduction, Agricultural Research Organization, \\ The Volcani Center, P.O.B. 6, Bet Dagan, Israel \\ * Department of Pathology and Electron Microscopy, \\ Beilinson Hospital, Petah Tiqwa
}

\section{SUMMARY}

Bulls treated with ethylene dibromide (EDB), either by oral administration of ten doses of $4 \mathrm{mg} / \mathrm{kg}$ body weight on alternate days or by a single intraperitoneal injection of $110-120 \mathrm{mg}$ of this compound into the fluid surrounding each testis, exhibited sperm malformations up to total disintegration of the sperm cells. The malformations appeared in the ejaculates collected about two weeks after the first oral dose or after the injection, and persisted for about one and two months after the last oral dose or the injection, respectively. It appears that ethylene dibromide interferes with the normal processes of spermiogenesis and sperm maturation.

\section{INTRODUCTION}

Most of the known spermicidal agents belong to classes of compounds which in order to be effective must be given in doses that are toxic or lethal (MANN, I964). In addition to its application as a male chemosterilant, a spermicidal compound which does not affect the health or libido of the animal can contribute to a better understanding of the male reproductive function by a study of its mode of action.

Previously, AmIr and VolcANI (I965) reported that oral administration of $4 \mathrm{mg} / \mathrm{kg}$ body weight ethylene dibromide (EDB) on alternate days for three weeks to a I6month-old bull, resulted in abnormal spermatozoa in semen collected from about two weeks after the start of the treatment. Normal semen was again collected

(1) Contribution from the Agricultural Research Organization, The Volcani Center, P. O. B. 6, Bet Dagan, Israel. I972 Series, no. 22I5-E. 
2-3 months after discontinuation of the treatment. The health and libido of the animal were not affected during the experimental period, even when the treatment was prolonged - in some animals - for several months (AMIR and VoLCANI, I965). EDB serves as a fumigant for stored grains and can be found in residual quantities in the concentrates of the animal ration.

In the present work the sequence and details of sperm structural changes induced by oral administration of EDB were studied and compared with those induced hy a single injected dose of this compound.

\section{MATERIALS AND ME'THODS}

Five Isvaeli-Friesian bulls, I5-20 months old, were used. They were trained to serve an artificial vagina from the age of 12 months and a body weight of $35^{\circ} \mathrm{kg}$. During the experiment their weight varied from $4^{\text {oo }}$ to $600 \mathrm{~kg}$. These animals were fed roughage ad libitum and a daily ration of 6-1o $\mathrm{kg}$ concentrates.

EDB was dissolved in olive oil at a concentration of $200 \mathrm{mg} / \mathrm{ml}$. Three bulls were given ten doses orally, each containing $4 \mathrm{mg} E D B / \mathrm{kg}$ body weight. The EDB was administered in gelatin capsules with the aid of a ball-gun on alternate days.

Two other bulls were injected, into the intraperitoneal liquid surrounding each testis beneath the tunica-vaginalis, with I I0-1 $20 \mathrm{mg}$ EDB in $0.55-0.60 \mathrm{ml}$ olive oil. After general anaesthesia with chloral-hydrate, an incision of $3-5 \mathrm{~cm}$ was made in the scrotum. A syringe needle was then inserted through the tunica vaginalis until a drop of the liquid which surrounds the testis appeared at the open end of the needle. The syringe containing the EDB was then connected to the needle and the compound was injected.

Semen was collected under field conditions usually 2-3 times per week, before, during and for 2-3 months after the treatment period. Generally one ejaculate was collected each time. Sperm motility was estimated microscopically, $i . e$. , the percentage of motile sperm was assessed subjectively by microscopic examination of samples, after dilution with $0.9 \mathrm{p}$. Ioo $\mathrm{NaCl}$, in a warm stage at $\times$ roo magnification. The sperm density was measured with a Klett-Summerson colorimeter calibrated against haemocytometer counts. Sperm smears were prepared and stained with Giemsa stain (HANCock, 1952). A total of at least 4 oo spermatozoa taken at random were observed in each smear-slide under an immersion objective ( $X$ I ooo), and the sperm abnormalities were recorded. These abnormalities included the presence of protoplasmic droplets ; coiled, bent or looped tails ; broken tails ; absence of tails ; acrosomic defects such as swelling, shrinking or folding and loss of the acrosome (denuded heads) ; and misshapen and disintegrating or degenerating heads.

For electron microscopy both negative-stained whole spermatozoa and sectioned spermatozoa were observed in a JEM $7 \mathrm{~A}$ electron microscope. For a negative staining a 2 p. roo phosphotungstic acid solution adjusted to $\mathrm{pH} 7.0$ with $\mathrm{NaOH}$, served as the negative stain, and Photo Flo 200 (Kodak) as surface active material. For electron microscopy of sectioned spermatozoa, five volumes of $2 \mathrm{p}$. 100 glutaraldehyde in $0.1 \mathrm{M}$ cacodylate buffer ( $\mathrm{pH} 7.2$ ) were added to one volume of the sperm suspension (after being concentrated by centrifugation). After one hour, the spermatozoa were washed five times at about Io-mn intervals with cacodylate buffer and then transferred to I p. Ioo osmic acid in cacodylate buffer for one hour. After two washings, at a I 5-mn interval, with the same buffer, the preparations were processed through upgraded alcohols for two hours. The preparations were then transferred to a mixture of ethanol and propyleneoxide ( $I: I$ ) and left overnight. The specimens were embedded in Epon-8I 2 according to LUFT (I96I). The sections were stained with uranyl acetate and lead citrate.

\section{RESUITS}

Oral administration of $E D B$. - The sequence and details of sperm structural changes are presented in table $I$ and in plates $I$ and 2. During the third week after the start of the treatment $25-98 \mathrm{p}$. Ioo of the spermatozoa in the collected ejaculates 
showed abnormalities, mainly coiled tails, acrosomic defects and acrosomic loss. From the fourth week until about 40 days after the start of the treatment, or three weeks after its discontinuation, 9o-roo $\mathrm{p}$. Ioo of the ejaculated spermatozoa were abnormal. Sixty to seventy percent of the abnormal spermatozoa showed various degrees of disintegration and degeneration, from shrinkage of the sperm head to complete breakage of the middle piece and lysis of the chromatin. During this period sperm motility decreased significantly. In the ejaculates collected during the 7 th and 8th weeks after the start of the treatment, or about one month after its discontinuation, the percentage of abnormal spermatozoa decreased, the sperm heads recovered their normal shape, and the sperm motility increased. Ejaculates with a percentage of abnormal spermatozoa similar to the pretreatment period were obtained about two months after the first dose or about 40 days after the last dose of EDB. The timing of the appearance and disappearance of abnormal spermatozoa was similar to that reported previously (AMIR and Vor,CANI, 1965). The sperm density was not affected significantly by the treatment in two out of the three animals.

TABLE I

Sperm characteristics and motility in bulls treated orally with ten doses of $E D B(4 \mathrm{mg} / \mathrm{kg}$ body weight/dose) on alternate days

Caractéristiques du sperme et motilité chez les taureaux traités à l'EDB par voie orale

\begin{tabular}{|c|c|c|c|c|c|c|}
\hline \multirow{3}{*}{$\begin{array}{c}\text { Days after } \\
\text { start } \\
\text { of treatment }\end{array}$} & \multirow{3}{*}{$\begin{array}{c}\text { Number } \\
\text { of sperm } \\
\text { collections }\end{array}$} & \multirow{3}{*}{$\begin{array}{l}\% \text { Abnormal } \\
\text { spermatozoa } \\
\text { (range) }\end{array}$} & \multicolumn{3}{|c|}{$\%$ Abnormalities } & \multirow{3}{*}{$\begin{array}{c}\text { Sperm } \\
\text { motility } \\
\text { (\% motile } \\
\text { cells) } \\
\text { Mean } \pm \mathrm{SE}\end{array}$} \\
\hline & & & \multirow{2}{*}{$\begin{array}{l}\text { Tail and } \\
\text { acrosome } \\
\text { defects }\end{array}$} & \multicolumn{2}{|c|}{ Misshaped heads } & \\
\hline & & & & Pear-shaped & Degenerating & \\
\hline \multicolumn{7}{|l|}{ Bull No. 98} \\
\hline Pre-treatment & 4 & 4-9 & 90 & 8 & 2 & $65 \pm \quad 2.9$ \\
\hline 0.14 & 7 & $3-14$ & 90 & 7 & 3 & $66 \pm 1.7$ \\
\hline $16-21$ & 3 & $25-98$ & 96 & 3 & 1 & $25 \pm 17.6$ \\
\hline 23-39 & 7 & $90-100$ & 11 & 7 & 82 & $3 \pm 1.8$ \\
\hline $42-53$ & 4 & $13-57$ & 63 & 7 & 30 & $55 \pm 8.7$ \\
\hline $64-75$ & 4 & $9-14$ & 88 & 7 & 5 & $65 \pm \quad 2.9$ \\
\hline \multicolumn{7}{|l|}{ Bull No. 573} \\
\hline Pre-treatment & 4 & $7-10$ & 89 & 8 & 3 & $50 \pm 8.9$ \\
\hline $7-11$ & 3 & $9-11$ & 89 & 8 & 3 & $47 \pm 6.0$ \\
\hline $14-16$ & 2 & $67-79$ & 96 & 3 & 1 & $3 \pm 0.0$ \\
\hline $20-35$ & 5 & $88-98$ & 7 & 0 & 93 & $4 \pm 1.9$ \\
\hline $39-53$ & 4 & $14-87$ & 35 & 57 & 8 & $42 \pm 7.8$ \\
\hline $57-64$ & 3 & $9-12$ & 68 & 27 & 5 & $57 \pm 7.5$ \\
\hline \multicolumn{7}{|l|}{ Bull No. 879} \\
\hline Pre-treatment & 4 & $5-17$ & 83 & 13 & 4 & $42 \pm 11.6$ \\
\hline $0-15$ & 7 & $6-12$ & 85 & 12 & 3 & $41 \pm 6.3$ \\
\hline $17-21$ & 3 & $77-85$ & 95 & 3 & 2 & $9 \pm \quad 5.3$ \\
\hline $25-35$ & 5 & 100 & 3 & 42 & 55 & $5 \pm \quad 3.7$ \\
\hline $38-52$ & 5 & $14-72$ & 56 & 39 & 5 & $53 \pm 2.0$ \\
\hline $56-61$ & 3 & $6-10$ & 81 & 15 & 4 & $47 \pm 1.7$ \\
\hline
\end{tabular}


Injected $E D B$. - Up to $50 \mathrm{p}$. Ioo abnormal spermatozoa, mainly tailless or with coiled tails, were found in the ejaculates collected during the third week after injection (table 2). During the fourth and fifth weeks, up to $80 \mathrm{p}$ : Ioo of ejaculated spermatozoa were abnormal, mainly with misshapen heads. These abnormalities did not affect significantly the percentage of motile cells. Indeed, the percentage of degenerating sperms and the degree of sperm degeneration were lower than in the bulls which were treated orally, probably because of the difference in the administered doses. A preliminary study showed that with an even smaller injected dose (50 mg into each side), only $37 \mathrm{p}$. Ioo of ejaculated spermatozoa were abnormal. Recovery took 3-4 weeks and normal ejaculates were collected about two months after the injection.

\section{TABLE 2}

Sperm characteristics and motility

in bulls injected intraperitoneally beneath the tunica vaginalis with $220-240 \mathrm{mg} E D B$

Caractéristiques du sperme et motilité

chez des Taureaux traités à l'EDB par injection sous la tunica vaginalis

\begin{tabular}{|c|c|c|c|c|c|c|}
\hline \multirow{3}{*}{$\begin{array}{l}\text { Days after } \\
\text { injection }\end{array}$} & \multirow{3}{*}{$\begin{array}{l}\text { Number } \\
\text { of sperm } \\
\text { collections }\end{array}$} & \multirow{3}{*}{$\begin{array}{c}\% \text { Abnormal } \\
\text { spermatozoa } \\
\text { (range) }\end{array}$} & \multicolumn{3}{|c|}{$\%$ Abnormalities } & \multirow{3}{*}{$\begin{array}{c}\text { Sperm } \\
\text { motility } \\
\text { (\% motile } \\
\text { cells }) \\
\text { Mean } \pm \mathrm{SE}\end{array}$} \\
\hline & & & \multirow{2}{*}{$\begin{array}{l}\text { Tail and } \\
\text { acrosome } \\
\text { defects }\end{array}$} & \multicolumn{2}{|c|}{ Misshaped heads } & \\
\hline & & & & Pear-shaped & Degenerating & \\
\hline \multicolumn{7}{|l|}{ Bull No. 92} \\
\hline Pre-treatment & 4 & $6-13$ & 83 & 11 & 6 & $55 \pm 7.6$ \\
\hline $1-13$ & 6 & 5- 8 & 76 & 17 & 7 & $63 \pm \quad 3.1$ \\
\hline $15-22$ & 4 & $8-21$ & 56 & 34 & 10 & $52 \pm \quad 5.2$ \\
\hline $26-36$ & 4 & $45-80$ & 12 & 65 & 23 & $52 \pm 10.1$ \\
\hline $39-65$ & 5 & $20-33$ & 51 & 36 & 12 & $49 \pm 5.1$ \\
\hline $70-78$ & 2 & $8-16$ & 67 & 22 & 11 & $67 \pm \quad 2.5$ \\
\hline \multicolumn{7}{|l|}{ Bull No. 99} \\
\hline Pre-treatment & 3 & $8-16$ & 91 & 5 & 4 & $47 \pm 3.3$ \\
\hline $1-9$ & 3 & $10-15$ & 97 & 3 & 0 & $45 \pm 2.9$ \\
\hline $12-18$ & 4 & $30-50$ & 75 & 19 & 6 & $49 \pm 7.8$ \\
\hline $20-27$ & 4 & $27-42$ & 43 & 52 & 5 & $45 \pm 6.4$ \\
\hline $30-55$ & 10 & 14-34 & 80 & 12 & 8 & $52 \pm 4.0$ \\
\hline $58-72$ & 4 & $6-14$ & 81 & 9 & 10 & $47 \pm 3.3$ \\
\hline
\end{tabular}

\section{DISCUSSION}

The results of this study showed that I2-I7 days after the start of the oral treatment or after the injection, the ejaculates collected from the treated bulls contained a high percentage of spermatozoa with coiled tails, and defects and loss of the acrosome. Abnormalities of this nature appear to arise in the epididymis (Gustafsson, I966). The time-lapse between the administration of EDB and the 
appearance of the first abnormal spermatozoa, which was found to be similar to the duration of the sperm epididymal transit in bulls from which 2-3 ejaculates per week were collected (ORGFBIN-CRIST, I962), and the nature of the obtained sperm abnormalities, suggest that ethylene dibromide interferes firstly with the normal function of the epididymis. However, in the ejaculates collected from the fourth week after the start of the oral treatment, the predominant spermatozoal abnormalities were misshapen heads upto their total disintegration and degeneration. These abnormalities seem to originate in the testes during spermiogenesis. The period of three weeks during which these abnormalities were observed in the ejaculates coincides with the duration of spermiogenesis (I9-20 days) in the bull (HocHEREAU, Courot and OrTAVANT, I964). The mechanism by which EDB affects the normal shape of the spermatozoa was not investigated in the present study. However, its spermicidal action appears to be specific to bulls. In a previous study (AMrR, r969), two adult rams of the Awassi and German mutton Merino breeds were given increasing doses of this compound by mouth for more than 4 months, up to their death from acute poisoning. No spermatozoal or other changes were observed in their ejaculates and even spermatozoa collected from the tail of the epididymis after death appeared to be normal.

Sperm characteristics and the fertility of cocks also remained unchanged even after I05 daily oral doses of about $7 \mathrm{mg} \mathrm{EDB} / \mathrm{kg}$ body weight (ALUMoT et al., I968). EDB doses up to roo $\mathrm{mg} / \mathrm{kg}$ body weight given to rats for several weeks failed to decrease their fertility (R. VoLCANI and U. IAAVON, I966, personal communication).

In this study one single intraperitoneal dose of $220-240 \mathrm{mg}$ injected into the fluid which surrounds the testes, caused an effect similar to, although less acute than, that caused by $20 \mathrm{~g}$ given orally to a bull weighing $500 \mathrm{~kg}$. In spite of the more acute effect caused to the spermatozoa after the oral treatment, the recovery period was shorter for these animals than for the injected bulls. Normal ejaculates were collected in the orally treated animals about 40 days after discontinuation of the treatment, whereas in the injected animals normal semen was collected 58-70 days after the injection.

Reçu pour publication en janvier 1973.

\section{RÉSUMÉ}

\section{MODIFICATIONS DE LA STRUCTURE DES SPERMATOZOÏDES DU TAUREAU APRÈS ADMINISTRATION ORALE OU INJECTION D'ÉTHYLÈ̀NE DIBROMIDE (EDB)}

L'éthylène dibromide utilisé pour la préservation du grain est un chemostérilisant, chez le Taureau, qui n'intervient pas sur le comportement sexuel. L'étude de son action au niveau de la spermatogenèse fait l'objet du présent travail.

Des taureaux traités à l'éthylène dibromide (EDB) soit par voie orale (Io doses de $4 \mathrm{mg} / \mathrm{kg}$ poids vif, à raison d'une dose tous les 2 jours), soit par une injection de I Io-I $20 \mathrm{mg}$ dans le liquide qui entoure chaque testicule, présentent des malformations des spermatozoïdes allant jusqu'à la désintégration totale de la tête spermatique. Les malformations apparaissent dans les éjaculats collectés à partir de I 5 jours environ après le début du traitement oral ou l'injection. Les premières malformations concernent seulement la queue et l'acrosome ; ensuite apparaissent les malformations et la dégénérescence de la tête des spermatozoïdes. 
Les éjaculats redeviennent normaux $\mathrm{I}$ et 2 mois après la fin du traitement oral ou l'injection, respectivement.

Il semble que l'EDB intervient sur les processus normaux de la spermiogenèse dans le testicule et sur la maturation des spermatozoïdes dans l'épididyme des Taureaux.

\section{ACKNOWLEDGEMENTS}

This research was financed in part by a grant made by the United States Department of Agriculture under P. L. 480 , The authors are indebted to Dr. A. TADMor for the surgical work needed to inject the animals and to $\mathrm{Mr}$. J. COHEN for preparation of the electron microscope.

We are also grateful to Professors R. Ortavant and G. M. H. Waites, for reading the manuscript and for their valuable suggestions, and to Dr. B. P. Setchell for his interest.

\section{REFERENCES}

Alumot E., Nachtomi E., Kempenich-Pinto O., Mandel E., Schindler H., I968. The effect of ethylene dibromide in feed on growth, sexual development and fertility of chickens. Poultry Sci., 41, I979-1985.

AMIR D., I967. The action of ethylene dibromide on rams. In : Mechanism of Halogenated Hydrocarbons Used as Fumigants on Animals. First Annual Report to U. S. Department of Agriculture, submitted by $A$. Bondi and E. Alumot, Project no. Aro-MG-8.

Amir D., Volcani R., 1965. Effect of dietary ethylene dibromide on bull semen. Nature, Lond., 106, $99 \cdot$ IOOO.

Gustafsson B., I966. Luminal contents of the bovine epididymis under conditions of reduced spermatogensis, luminal blockage and certain sperm abnormalities. Acta Vet. Scand. Suppl., 17, I-80.

HANCock J. L., I952. The morphology of bull spermatozoa. J. exp. Biol., 29, 445-453.

Hochereau J. T., Courot M., Ortavant R., I964. Durée de la spermatogenèse chez le taureau; étude par autoradiographie təsticulaire. Proc, 5th Int. Congr. Anim. Reprod., Trento, 3, 54I-546.

LUFT J. H., rg6r. Improvements in epoxy resin embedding methods. J. Biophys. Biochem. Cytol., 9, 409-4I4.

MAN T., I964. The Biochemistry of Semen and of the Male Reproductive Tract. Methuen, London.

ORGEBIN-CRIST M. C., I962. Recherches expérimentales sur la durée de passage des spermatozoïdes dans l'épididyme du taureau. Ann. Biol. anim. Bioch. Biophys., 2, 5 r-ro8.

\section{PLATE I}

Sperm smears from a bull treated orally with ten doses of $4 \mathrm{mg} / \mathrm{kg}$ body weight ethylene dibromide given on alternate days.

The smears are from ejaculates collected $9, \mathrm{r} 7,24,32,40,48$ and 54 days after the start of the treatment (fig. I-7, respectively). Giemsa stain ( $X$ I.500).

Frottis de sperme d'un Taureau traité à l'éthylène dibromide par voie orale.

Les collectes ont eu lieu 9, 17, 24,32, 40,48 et 54 jours après le début du traitement (fig. 1 à 7 respectivement). 

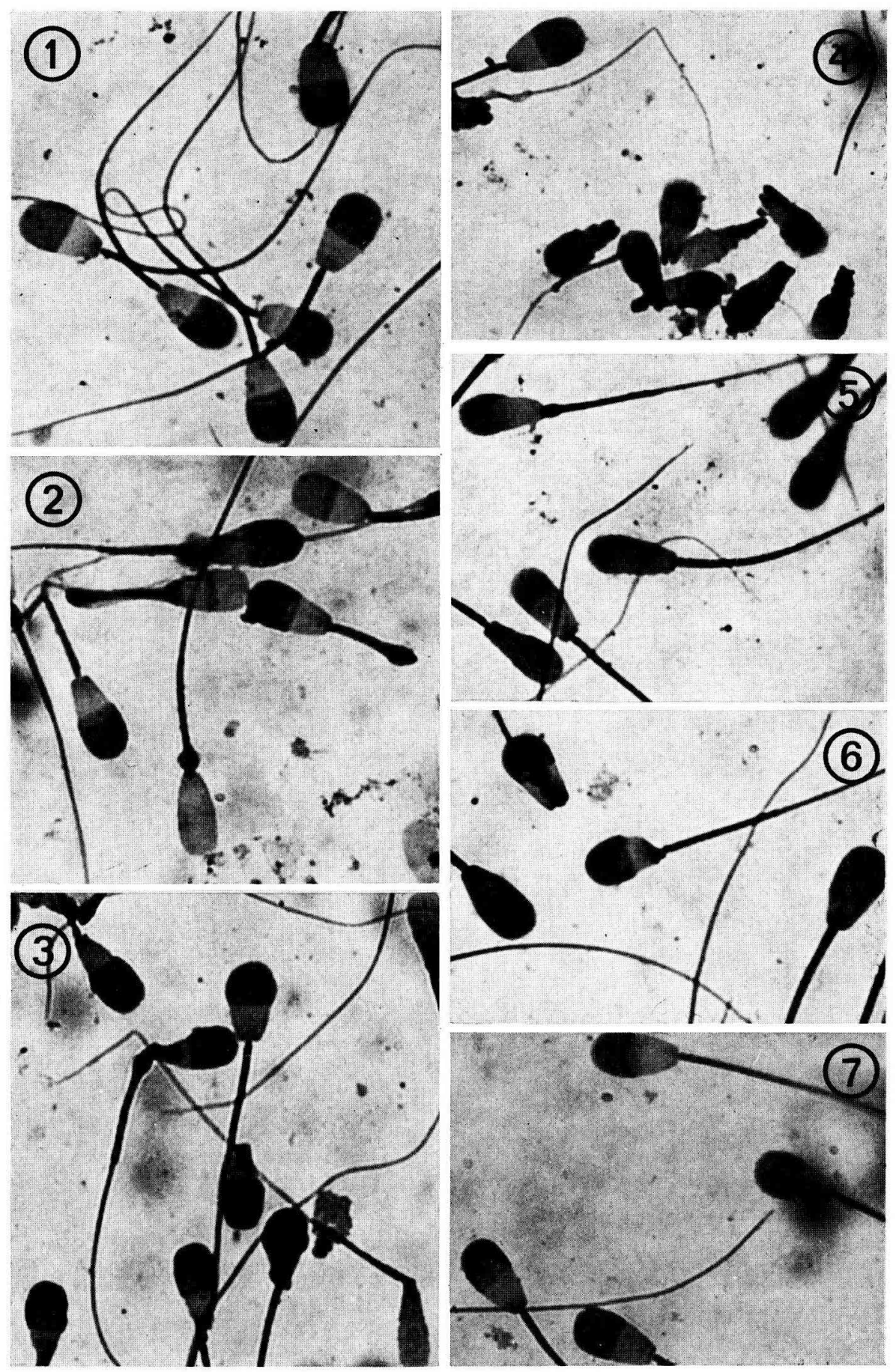

D. AMIR and E. BEN-DAVID 
PLATE 2

Electron microphotographs of bull spermatozoa from an untreated animal and from an animal treated orally with ethylene dibromide.

Microscopie électronique de spermatozoïdes de Taureau. Un animal non traité et un animal traité à l'éthylène dibromide par voie orale.

FIG. 1

Negative stained $(\times 9,500)$ normal spermatozoon collected from an untreated bull.

Spermatozoïde normal d'un Taureau non traité.

FIG. 2 and 3

Negative stained $(\times 6,500)$ and longitudinally sectioned $(\times 25,000)$ spermatozoa collected 28 days after the start of treatment. Note lysis of the chromatin and disintegration of the middle piece.

Spermatozoïdes récoltés 28 jours après le début du traitement. Sur la coupe longitudinale, noter la lyse de la chromatine et la désintégration de la pièce intermédiaire. 

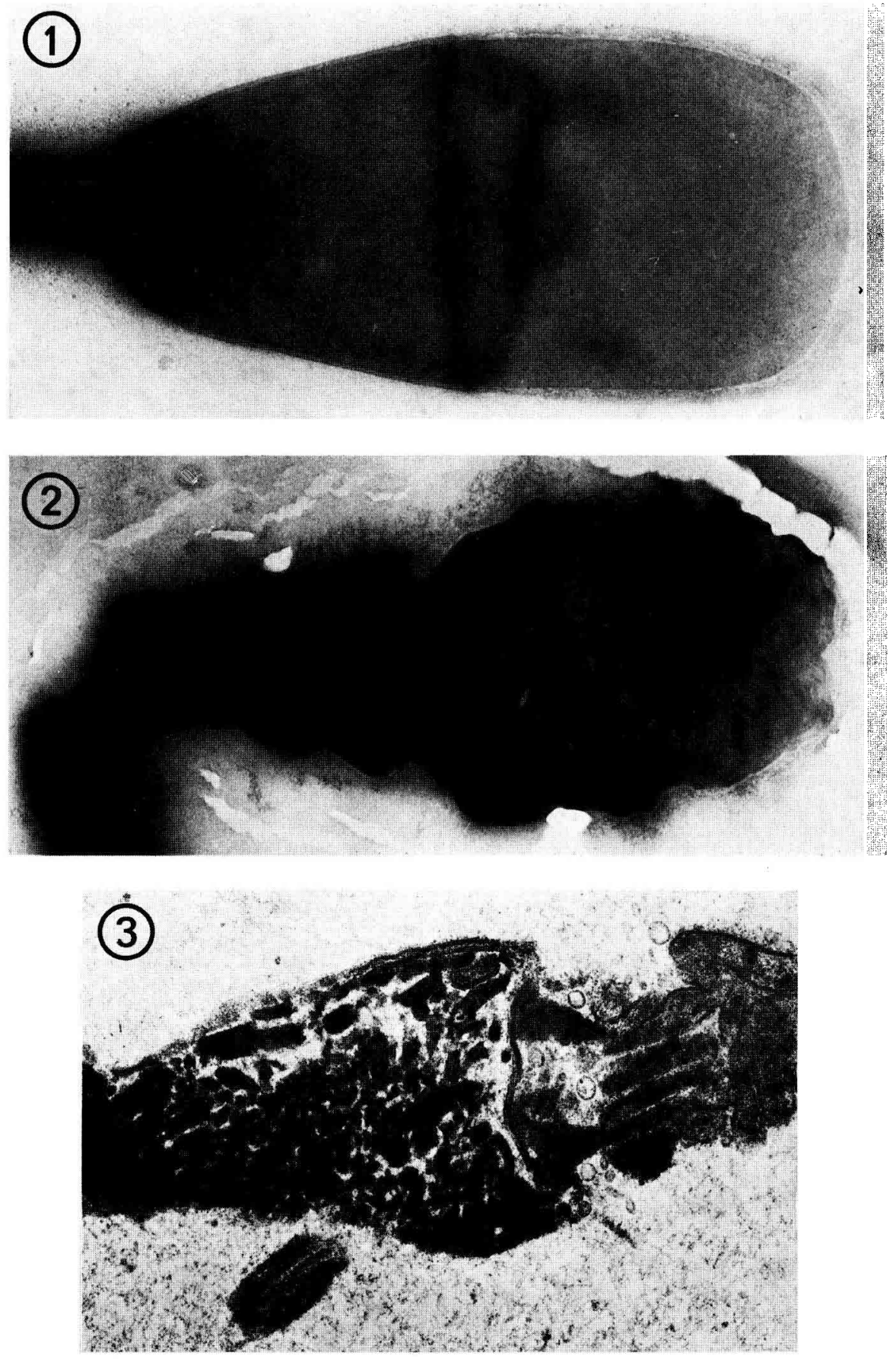

D. AMIR and E. BEN-DAVID 